\title{
Tyrkiet har skiftet ham, men ikke spor
}

\section{Martin Selsøe Sørensen}

EU-processen er gået helt i stå, og Tyrkiet er begyndt at gå egne veje i sit nabolag. Det danske EUformandskab kan næppe redde den proces, men det kan stadig gøre noget for at fremme Tyrkiets integration i Europa

Tangoen mellem EU og Tyrkiet er gået helt i stå, og det skyldes ikke kun, at EU ikke vil svinge om. Tyrkiet gør meget lidt for at gøre sig attraktiv som dansepartner. Hvor man kunne forvente, at et EU-kandidatland ville afstemme sin politik med EU's, så vælger Tyrkiet gang på gang at gå i den modsatte retning eller gøre for lidt i forhold til forventningerne i EU-landene.

Den tyrkiske regering er ellers i teorien enig $i$, at tango er bedre end solodans, som man kunne læse i The Guardian for nylig:

"Værdien af det europæiske projekt forbliver klar for os, selv i disse turbulente tider. Nationer, der står sammen, klarer sig bedre end dem, der står alene og som en indsats for at højne ligheder frem for forskelligheder, er EU en unik frembringelse.
Integration er det princip, der har bragt Europa til historiske højder af sikkerhed, fred og velfærd og fordelene er mere relevante end nogensinde", skrev den tyrkiske europaminister Egemen Bagis i en kommentar.

Efteråret og sensommerens dramatiske nedkøling af forholdet til Israel er et eksempel på en politik, der gør det meget svært at forestille sig Tyrkiet som medlem, særligt for EU-lande, der i forvejen finder det for stort, for anderledes og ikke mindst for muslimsk.

\section{Nedkøling til Israel}

Tyrkiet og Israels indbyrdes relation har været problemfyldt siden Israels krig mod Gaza i julen 2009, og blev forværret af episoden med den tyrki- 
ske nødhjælpsflotille til Gaza, der blev angrebet af den israelske flåde natten til den 1 . juni sidste år. Ni tyrkere døde, og siden fulgte måneder med hemmelige forhandlinger om formulering af en israelsk undskyldning og størrelsen af en erstatning til de dræbtes familier. Flere gange var der stærke forlydender om, at en aftale var på vej, men hver gang blev nyheden lækket til pressen i utide og aftalen udskudt.

I sensommeren i år afslørede New York Times udkastet til en FN-rapport, der til Tyrkiets vrede ikke fordømte det israelske angreb og på et øjeblik trak Ankara sin ambassadør i Tel Aviv hjem og nedfrøs alle forbindelser til Israel undtagen de handelsmæssige.

Som ekstra trumf har ministerpræsident Recep Tayyip Erdogan garanteret, at tyrkiske krigsskibe vil patruljere nær Gazas kyster og assistere eventuelle fremtidige nødhjælpsskibe ind til Gaza. Dem er der ikke så mange af, så indtil videre har det ikke vist sig nødvendigt, men signalet til Israel og EU er ikke til at tage fejl af.

Det er givet, at regeringen i Ankara har opfanget signaler i den diplomatiske æter om, at både Washington og EU-landene ikke længere er så minutiøst optagede af Israel-Palæstina-spørgsmålet, som de var engang, og særlig tydeligt blev det sidste forår, da Israels ministerpræsident Benyamin Netanyahu fik en kold skulder og en bagdør ud af Det
Hvide Hus efter et møde med præsident Barack Obama.

Det signal kan Tyrkiet meget vel have opfattet som et grønt lys til Israel bashing, hvad det måske også var, men næppe i den grad Tyrkiet siden er gået til den. Selv om en stribe EU-lande også har problemer med den nuværende israelske regerings politik, er hjemtagning af ambassadører og trusler om krigsskibe værktøjer, der dårligt nok eksisterer i EU.

Ved valget af Anders Fogh Rasmussen til generalsekretær for NATO var den tyrkiske modstand mod hans kandidatur så voldsom og krævede så mange diplomatiske greb fra blandt andre Barack Obama og Silvio Berlusconi, at man ikke kan fortænke nogen i at overveje en ekstra gang, hvordan det helt præcist ville se ud, hvis Tyrkiet sad med som fuldgyldigt medlem af EU og gang på gang var på tværs af beslutninger, som resten af kredsen var blevet enige om. Ikke at der ikke er uenighed og særstandpunkter i EU allerede, der er bare grænser for hvor langt andre lande forfægter dem. Ikke mindst i kandidatfasen.

\section{Ytringsfrihed truet}

Hjemme i Tyrkiet har regeringen sværere og sværere med at beskytte den ytringsfrihed, der er så vigtig for EU, men som tydeligvis ikke får den store opmærksomhed og omsorg i Tyrkiet. Landet overgår nu Kina i 
antallet af fængslede journalister og har dermed en trist verdensrekord, selv om regeringen insisterer på, at de fleste af journalisterne blot er varetægtsfængslede og det for forbrydelser, der ikke har med journalistik at gøre.

Det er der ikke mange hverken i Tyrkiet eller udenfor, der tror på, men formelt har regeringen ret.

I virkeligheden er der tale om en udbredt og voksende intolerance $\mathrm{i}$ regeringskontorerne i Ankara overfor kritik eller bare dissens.

Fælles for mange af de fængslede er, at de mener anderledes end regeringen om det kurdiske spørgsmål, der er blevet det vigtigste indenrigspolitiske emne de senere år. Den tyrkiske regering og Erdogan personligt har sat sig for at udmanøvrere det pro-kurdiske parti BDP og selv erobre pladsen som kurdernes foretrukne stemme og håb. Målt på vælgertilslutning er det lykkedes, men meget er ikke nok for en ministerpræsident, der vil have det hele.

Hundreder af BDP-medlemmer og administratorer, menneskerettighedsforkæmpere, journalister og forlæggere er de seneste uger og måneder blevet arresteret - typisk ved natlige anholdelsesbølger - og anklaget for medlemskab af den forbudte kurdiske paraplyorganisation KCK, der blandt andet rummer PKK.

Ingen kan bevise, at politiet er sendt i byen af regeringen, men det behøver de heller ikke. Bureaukra- ter og offentligt ansatte i Tyrkiet har altid vidst at forvalte deres embeder til den politiske ledelses velbehag, hvis de var interesserede i forfremmelser. Distriktsguvernører forstår at tilgodese byer og landsbyer, der stemmer på det til enhver tid siddende regeringsparti. Gør de det og gør de det godt, kan de regne med at blive forfremmet til finere distrikter og hele guvernementer. Det behøver ingen fortælle dem.

Ifølge iagttagere tyder meget de senere år på, at der i politiet og anklagemyndigheden er opstået en gruppe, der deler regeringens religiøse og politiske synspunkter.

I sagerne med de KCK-anklagede er der ofte ingen substans i anklagerne. Tyrkisk politi er berygtet for at skride til anholdelse på løse mistanker for så først at indlede efterforskningen, når den mistænkte er bag tremmer. På den måde kan man snildt ende med varetægtsfængsel i mere end 18 måneder, inden man bliver løsladt uden videre tiltale, undskyldning eller erstatning.

For fem år siden talte man fra EU's side meget om en paragraf 301 i den tyrkiske straffelov, der forbød 'fornærmelser mod tyrkiskhed'. En fjernelse af den blev gang på gang nævnt som et kriterium for tyrkisk avancement i optagelsesforhandlingerne, men allerede dengang var det åbenbart, at det var en dum politik. Tyrkiet endte med en omformulering af paragraf 301, der begrænsede antallet af ytringsfriheds- 
sager for en stund, men undlod at lade en fundamental accept af ytringsfrihed i europæisk forstand synke ind.

Fordi EU stirrede sig blind på paragraf 301, kom de andre aldrig på dagsordenen, og efter lovændringen gik EU videre til at se Cypern som sin hovedbekymring i stedet for at sikre, at ikke bare signalet, men også budskabet var modtaget.

\section{Ingen folkesag}

Til den tyrkiske regerings held er ytringsfrihed ikke nogen folkesag i Tyrkiet. Med undtagelse af en lille flok journalister, forfattere og intellektuelle er ytringsfrihed ikke noget, den jævne tyrker bekymrer sig om, fordi de aldrig selv kommer i konflikt med paragrafferne. De kunne ikke drømme om at kritisere hverken Atatürk eller præsidenten, og de går ikke op i kurdernes krav om kulturelle rettigheder. De bekymrer sig til gengæld om, hvordan dagen i morgen bliver bedre end dagen $\mathrm{i}$ dag, og hvordan deres børn får et bedre liv.

Tyrkiet har ikke forladt EU-sporet, men efter i et par at have kørt lyntog mod Bruxelles, har landet de seneste fem år sagtnet farten så meget, at det ikke er til at se bevægelse med det blotte øje. Forklaringer er der mange af, men de to bedste er, at EU har skuffet, og at perspektivet mildt sagt er tåget.

I 2004 afgjorde Den Europæiske
Menneskerettighedsdomstol i Strasbourg, at det var i orden, at tyrkiske Leyla Sahin blev forment adgang til medicinstudiet, fordi hun bærer hovedtørklæde. Tyrkiet har siden 1997 opretholdt et forbud mod hovedtørklæder på statslige institutioner, og domstolen gav overraskende staten ret $\mathrm{i}$, at det er rimeligt, fordi der er en fare for, at statens sekulære fundament kan erodere, hvis tørklæder tillades.

Det var en fæl overraskelse for Recep Tayyip Erdogans regering, der indtil da havde regnet med, at EU i alle spørgsmål om frihedsrettigheder kunne bruges som rambuk mod de gamle udemokratiske institutioner. Det kunne EU ikke og det tilmed i et spørgsmål med enorm symbolsk og praktisk betydning for regeringen og dens vælgere.

Samme år meddelte Frankrig og Tyskland, at de så Tyrkiets fremtid i et 'privilegeret partnerskab' som alternativ til fuldt medlemskab.

For optagelsesprocessen betød det, at den med det samme mistede momentum, fordi Tyrkiet fandt ud af, at det spor de var slået ind på, og som de troede havde fuldt medlemskab som endestation, nu pludselig stod til at løbe ud i sandet et eller andet sted før målet.

I dag er kun ét ud af 33 kapitler i EU's acquis communautaire forhandlet færdig. 13 er åbnet, og 19 er frosset af primært Frankrig eller Cypern oftest med henvisning til den uløste konflikt om Cypern. Et af 
de endnu åbne kapitler er det, der handler om miljø, hvor Tyrkiet vurderes at være helt ude af takt med EU's standarder og derfor står over for investeringer i størrelsesordenen 100 milliarder euro for at leve op til kravene.

Miljø er i forvejen ikke noget stort spørgsmål i Tyrkiet, og man kan ikke fortænke regeringen i at tøve med at investere 100 milliarder på et område, der ikke har dens egen eller befolkningens store (erkendte) interesse. Særligt ikke når investeringen ikke med sikkerhed bringer landet tættere på EU-optagelse.

\section{Fastholder EU-mål}

Trods de tågede udsigter kommer Tyrkiet aldrig til at opgive EU som erklæret mål, for det kan ingen tyrkisk regering tåle, uanset hvor lav tilslutningen til projektet måtte dykke i meningsmålingerne. EU-ankeret vil altid være en sikkerhed for både befolkning og udenlandske investorer for, at Tyrkiet ikke igen vil komme i drift mod udemokratiske systemer og militærkup, og det anker vil det være kostbart at slippe.

Men i takt med at Tyrkiets økonomi har vokset sig ind i G20, og EU's lavt voksende økonomi ikke kan absorbere alle de fladskærme og busser, tyrkerne gerne vil producere, er landet begyndt at se mod øst og syd. De mange kontroverser og skuffede forventninger mellem Bruxelles og Ankara har givetvis også været med til yderligere at inspirere Tyrkiet til at se sig om i sit nabolag efter andre muligheder for politisk kapital end et EU-medlemskab.

Siden Osmannerrigets kollaps har Tyrkiet i sin iver efter at hægte sig på Europa stort set ikke interesseret sig for sit mellemøstlige nabolag, der i lang tid ret beset heller ikke havde meget at tilbyde ud over olie og ballade.

Skiftende regeringer i Ankara var meget lang tid om at se dels det handels- og turismepotentiale, der ligger for Tyrkiet i mellemøstregionens voksende, købestærke middelklasse, dels den mulighed for politiske indflydelse, der også ligger regionalt. Både i forhold til regionens interne politik og i forhold til at være både tale- og hørerør for de arabiske lande og Iran på den ene side og Vesten og Israel på den anden.

Først for tre år siden fik Tyrkiet en aktiv naboskabspolitik, der begyndte med et udelukkende økonomisk sigte. Handelshindringer og visumkrav blev fjernet, og det banede vej for tyrkisk eksport af forbrugsvarer, banker, universiteter og byggeri. Den anden vej er kommet et tydeligt arabisk og iransk islæt, ikke bare i stormagasinerne i Istanbul, men også på badehåndklæder blandt russere og europæere på badestrandene.

I 2011 er der lagt en politisk dimension til politikken i og med, at Tyrkiet er begyndt aktivt at forsøge at orientere de kommende demo- 
kratier i Nordafrika i retning mod Tyrkiet selv. Der er gode historiske, sociale og religiøse grunde til, at det tyrkiske eksempel for markedsøkonomi, demokrati og religionens plads i samfundet er mere relevante for de arabiske befolkninger end Irans eller EU's, men for Tyrkiet er der mere i det end blot funktionen som forbillede. Med rollen som storebror følger også rollen som vejleder og mægler, og til gengæld håber Tyrkiet på politisk opbakning i internationale fora, når der skal vælges repræsentanter og gennemføres afstemninger.

Til yderligere $ø$ konomisk ekspansion og diplomatisk afstivning er Tyrkiet også begyndt at involvere sig i Afrika - et kontinent, som Ankara hidtil ikke har vist den store interesse. Som alverdens andre aspirerende regional- og stormagter har Tyrkiet involveret sig dybt med en stribe nye ambassader, direkte flyruter, tyrkiske skoler og stipendier til afrikanske studerende.

\section{Ny udenrigspolitik}

De nye retninger på tyrkisk udenrigspolitik kan ikke tages som udtryk for, at landet er ved at orientere sig væk fra Europa. Men hvor Tyrkiet tidligere udelukkende var orienteret $\bmod \mathrm{EU}$, har landet nu fået en mere moderne og multidimensional udenrigspolitik med den sideeffekt, at nationen har fået en helt ny tro på sig selv. Dengang Tyrkiet kun så mod Europa og målte sig mod EUlandene, endte Tyrkiet altid som nummer sidst på listerne, når der blev målt uddannelse, velstand, lighed og kvinders deltagelse. Kun på listen over korruption lå i Tyrkiet i top lige efter Grækenland. Den slags målinger gjorde ikke noget godt for selvtilliden hos et stolt folk.

I dag er det anderledes. Nu møder tyrkerne verden med en helt anden tro på sig selv, fordi de kan se, at der står respekt om Tyrkiets rolle som mægler og aktør i regionen og at landets erhvervsliv er stærkt repræsenteret $\mathrm{i}$ alle nabolande med en god hjemmeøkonomi til følge. Det er noget at være stolt over, og det har bidraget til opfattelsen i både befolkning og regering af, at Tyrkiet klarer sig fint alene.

Man kan ikke fortænke tyrkerne i, at de med beskeden om 'privilegeret partnerskab' får en ide om, at de ikke er velkommen i EU og derfor begynder at se sig om efter andre internationale partnerskaber og måder at konsolidere sig på. For den tyrkiske regering giver det tilmed mening at fortælle befolkningen, at de ikke er velkomne i EU, for så behøver den ikke fortsætte det reformprogram, der nu bliver vanskeligt og vil koste milliarder af euro uden nogen garanteret gevinst i form af EUmedlemskab.

At reformerne både først og sidst er for Tyrkiet og tyrkernes skyld er ikke altid et argument, der vinder indpas i et land, hvor for eksempel 
frihedsrettigheder ikke opfattes som basale, og miljøbeskyttelse ikke opfattes om livsnødvendig.

Regeringen og et stort flertal i befolkningen er enige om, at det ikke skal være tilladt at fornærme Atatürk, og at forsvar for mindretalsrettigheder ofte er lig støtte til terrorisme, og derfor er der intet pres for at garantere ytringsfriheden, som EU drømmer om.

Miljø er typisk noget man kun interesserer sig sporadisk for, og kun hvis der på kort sigt er penge at spare. Elsparepærer er blevet voldsomt populære de seneste år, det er affald i skraldespanden ikke.

Konsekvensen af den dalende interesse for EU-processen er, at den tyrkiske regering kan tillade sig unoder, den ikke kunne dengang, der stod dyb respekt om EU's årlige rapporter.

I disse år går det tilbage for ytringsfriheden og kurdernes repræsentation i politik, og i bedste fald er kvinders ligestilling gået i stå.

Løsningen på alle problemerne ligger hos regeringen, men den har ikke vist sig i stand eller villig til at tackle dem, fordi der ikke vurderes at være stemmer i pressefrihed og kvinderettigheder, og det har regeringen nok ret i. Tyrkiske vælgere er primært optagede af privatøkonomi og formulerer typisk ikke andre krav end forventningen om, at en regering leverer rammerne for et bedre liv - om ikke for dem selv så for deres børn.

\section{Visumkrav tilbage}

Det store tilbageværende problem for en regering, der ikke gider høre om demokrati og kun reformerer i sit eget tempo, er visumkravet. Tyrkiske forretningsfolk er vrede over, at de stadig skal stå i ydmygende køer ved EU-repræsentationerne rundt om i landet og producere stakkevis af papir for ofte korte visa for at lave forretninger i EU.

Tyrkeres fri bevægelighed i Europa er et af de knap så direkte udtalte forbehold ved tyrkisk medlemskab mange steder i Europa, men frygten er formentlig overdrevet, for tyrkerne kommer næppe til at søge mod Europa i hobetal, hvis grænserne blev åbnet bare på klem.

Allerede i dag rejser flere med tyrkisk baggrund til Tyrkiet fra Tyskland, end tyrkere rejser den anden vej, og i det hele taget er det nu i Tyrkiet mulighederne ligger også for unge sydeuropæere, der slås med lav vækst eller recession og høj ungdomsarbejdsløshed. Trods perspektiverne er det svært at forestille sig, at den tyrkiske regering i den nuværende situation for alvor kommer til at sætte fart på EU-processen.

Europaministeren Egemen Bagis har flere gange sagt, at for hver dag der går, behøver Tyrkiet EU mindre, mens EU behøver Tyrkiet mere. Når han siger det, glemmer han det han også siger om styrken ved at stå sammen, og det er netop det, der er 
den store gevinst for både Tyrkiet og EU ved tyrkisk medlemskab. Fuld tyrkisk deltagelse i EU vil give Unionen yderligere vægt både økonomisk og politisk og stille den stærkt over for både handelspartnere og de udfordringer, EU står overfor i sit nærområde efter det arabiske forår. Her har det været tydeligt, at af alle dem, der har talt er ham, der er lyttet mest til på den arabiske gade Erdogan. En kombination af hans appel og europæisk kapital og organisation vil gøre EU uovertruffen i Mellemøsten.

Desværre ser det ud til, at europaministerens temmelig arrogante og noget selvovervurderende holdning går igen flere steder i regeringen, hvor man nu mener, at kunne alting selv. I regeringskontorerne kan man meget vel have lavet den kalkule, at Tyrkiet aldrig bliver færdig med optagelsesforhandlingerne, og selv hvis det gør, så er det til den tid mere attraktivt for landet at forblive uden for Unionen. Uden for kan Tyrkiet agere selvstændigt i sin udenrigspolitik, som det er begyndt at gøre i dag, og samtidig bevare den tætte økonomiske integration med EU, det allerede har i dag i kraft af en toldunion.

\section{Dansk formandskab}

For det danske EU-formandskab bliver det svært, men ikke umuligt at ændre dynamikken i forholdet mellem Tyrkiet og Unionen. I øjeblikket løber al dialog mellem parterne panden mod Cypern, der er blevet den store forhindring for fremskridt. EU vil have Tyrkiet til at anerkende Cypern, om ikke andet så de facto ved at åbne havne og lufthavne for cypriotiske fartøjer. Omvendt mener Tyrkiet ikke, EU lever op til sine løfter om støtte til Nordcypern og lempelse af boykotten, og der strander forhandlingerne.

Det dødvande kan det danske formandskab ikke bryde, men det kan gøre som enhver, der befinder sig $\mathrm{i}$ en samtale, der er ubekvem: Det kan skifte emne. I stedet for at tage fat om de store spørgsmål om demokrati og Cypern kan det danske formandskab tage fat om de små, og fremme EU-integrationen på kommunal- og regionsniveau.

En lang række opgaver som affaldshåndtering, vejrenovering, legepladsbyggeri, etc. er ens, uanset om man er en dansk eller en tyrkisk kommune, og der er ting at lære begge veje. Ved at fremme integrationen på de lavere administrative niveauer undgår man store komplicerede og ofte abstrakte spørgsmål samtidig med, at man skaber forandringer meget tæt på borgernes hverdag. Det giver en dybere forståelse i Tyrkiet for, hvad EU også er, og hvorfor det kunne være en god ide at være med.

Martin Selsøe Sørensen er Politikens korrespondent $i$ Tyrkiet. 